\title{
PENGOLAHAN TEPUNG IKAN MUTU PANGAN DARI DAGING MERAH IKAN TUNA
}

\author{
Nurul Hak*), Tazwir*), Murdinah*), dan Mohammad Saleh*)
}

\begin{abstract}
ABSTRAK
Dalam penelitian ini telah dilakukan percobaan pengolahan daging merah ikan tuna menjadi tepung ikan mutu pangan. Tahap pertama dari percobaan ini ialah mendapatkan cara pemucatan daging merah ikan tuna dengan menggunakan larutan kalsium hipoklorit dan hidrogen peroksida sebagai bahan pemucat. Tepung ikan yang diolah dari daging yang sudah mengalami pemucatan kemudian dianalisis komposisi proksimat dan asam aminonya serta dicoba pemanfaatannya dalam pembuatan kerupuk. Hasil penelitian menunjukkan bahwa perlakuan perendaman dalam larutan hidrogen peroksida $1 \%$ selama 30 menit lebih efektif daripada dalam larutan hipoklorit. Pengamatan selanjutnya menunjukkan bahwa proses pemucatan lebih efektif jika daging dikukus terlebih dahulu sebelum direndam dalam larutan pemucat. Tepung ikan yang dihasilkan dari daging merah tuna yang sudah dipucatkan termasuk ke dalam kategori konsentrat protein tipe $B$ dan mengandung semua asam amino esensial. Jumlah optimum tepung ikan yang dapat ditambahkan ke dalam adonan kerupuk adalah 10\% dari bobot total bahan.
\end{abstract}

\section{ABSTRACT: Processing of foodgrade fish flour from tuna red meat. By: Nurul Hak, Tazwir, Murdinah, and Mohammad Saleh}

A study of food grade fish flour processing from tuna red meat have been exercized with the aim to optimize the utilization of by-product from canned and frozen tuna loin industries. The first step of experiment was to find out bleaching technique of tuna red meat using calcium hyphochlorite and hydrogen peroxide solution. Food grade fish flour produced from bleached red tuna meat was analyzed for its proximate composition and amino acid profile and then was used in fish cracker preparation. The results showed that dipping in hydrogen peroxide solution was more effective than in sodium hyphochlorite solution to bleach red tuna meat and bleaching was more effective if fish meat was cooked before the treatment. Fish flour produced was classified as type $B$ fish protein concentrate and contained all essential amino acids. The optimum weight of tuna fish flour in the preparation of fish cracker was 10 percent of raw material total weight.

KEYWORDS: food grade fish, tuna red meat

\section{PENDAHULUAN}

Hasil samping yang berasal dari industri pengolahan ikan masih banyak yang belum dimanfaatkan secara optimal bahkan ada yang dibuang sebagai limbah. Salah satu hasil samping industri pengolahan ikan yang masih dapat ditingkatkan pemanfaatannya adalah daging merah ikan tuna yang berasal dari pengolahan loin tuna beku dan pengalengan tuna. Selama ini hasil samping tersebut hanya diolah menjadi pakan ternak, hanya sebagian kecil yang diolah menjadi produk pangan antara lain dengan mengolahnya menjadi produk semacam sambal goreng atau sejenisnya.

Beberapa penelitian untuk mencari alternatif pemanfaatan daging merah ikan tuna telah dikembangkan untuk tujuan pangan, di antaranya untuk terasi (Nursyam, 1992), hidrolisat protein ikan (Nursyam et al., 1998), dan pasta ikan (Saleh et al.,
1995). Dalam penelitian ini dilakukan percobaan pengolahan daging merah ikan tuna menjadi tepung ikan mutu pangan. Dibandingkan dengan tepung ikan untuk pakan, tepung ikan mutu pangan mempunyai nilai ekonomis yang lebih tinggi karena pemanfaatannya lebih luas, antara lain sangat bermanfaat dalam pengkayaan (enrichment) protein berbagai produk pangan. Namun demikian persyaratan mutu tepung ikan mutu pangan lebih tinggi daripada untuk pakan, antara lain di samping faktor keamanan juga diperlukan persyaratan sifat fungsional dan kandungan gizinya.

Dalam penelitian ini telah dilakukan percobaan pengolahan daging merah ikan tuna menjadi tepung ikan mutu pangan yang diawali dengan percobaan untuk mendapatkan perlakuan pemucatan sebelum diolah menjadi tepung yang dilanjutkan dengan analisis mutu gizinya serta kemungkinan penggunaannya dalam pengolahan pangan sejenis kerupuk.

\footnotetext{
-) Peneliti pada Pusat Riset Pengolahan Produk dan Sosial Ekonomi Kelautan dan Perikanan
} 


\section{BAHAN DAN METODE}

\section{Bahan}

1. Daging merah ikan tuna

Daging merah ikan tuna yang digunakan dalam penelitian didapat dari pabrik pengolahan loin tuna beku di Muara Baru, Jakarta. Bahan yang akan digunakan untuk percobaan tersebut disimpan dalam keadaan beku pada suhu sekitar $-15^{\circ} \mathrm{C}$.

2. Larutan hidrogen peroksida teknis

3. Kalsium hipoklorit $\left\{\mathrm{Ca}(\mathrm{OCI})_{2}\right.$, kaporit\}

\section{Metode}

Penelitian dilakukan dengan tahap-tahap kegiatan sebagai berikut:

\section{Mendapatkan jenis dan konsentrasi bahan pemucat}

Dalam percobaan ini dilakukan pemucatan dengan cara merendam daging merah dalam dua jenis bahan pemucat yaitu larutan hidrogen peroksida dan kaporit. Pemucatan dilakukan dengan cara trial and error pada konsentrasi yang dinaikkan secara bertahap dari 0,5; 1,$0 ; 1,5 ; 2,0$ hingga $2,5 \%$; masing-masing untuk daging merah yang telah dikukus pada menit ke-30, 60,90 , dan 120. Pengamatan dilakukan secara visual dan dicatat hasil yang terbaik.

Selama perendaman sekali-sekali dilakukan pengadukan. Selesai perendaman daging ikan dicuci dengan air sebanyak 3 kali, setelah ditiriskan kemudian dilakukan pengamatan terhadap warna daging ikan secara visual. Teknik pemucatan terbaik yang diperoleh digunakan untuk tahap percobaan selanjutnya yaitu pembuatan tepung ikan mutu pangan dan pengolahan kerupuk.

\section{Pengolahan tepung ikan mutu pangan}

Daging merah tuna yang telah mendapat perlakuan pemucatan dan pemasakan digiling dengan alat penggiling daging, kemudian dikeringkan dalam oven pada suhu $80-85^{\circ} \mathrm{C}$ hingga kadar airnya mencapai sekitar 10\%. Bahan ini lalu digiling dengan mesin penepung, tepung ikan yang dihasilkan dikemas dalam kantong plastik untuk diamati mutu kimiawinya yang mencakup komposisi proksimat (Anonim, 1974), kandungan asam amino dengan HPLC dan residu hidrogen peroksida dengan cara titrasi (Anonim, 1979). Di samping itu juga dilakukan pengamatan mutu organoleptiknya (rupa, warna, bau, dan konsistensi) secara deskriptif.

\section{Pemanfaatan tepung ikan pada pengolahan kerupuk}

Dalam percobaan ini dicari jumlah tepung ikan yang dapat ditambahkan ke dalam adonan kerupuk yang dapat menghasilkan kerupuk dengan karakteristik mutu organoleptik yang disenangi panelis (penampakan, bau, rasa, dan kerenyahan). Konsentrasi tepung daging merah ikan tuna yang ditambahkan adalah sebanyak 0\%, 5\%,10\%, 15\%, $20 \%, 25 \%$, dan $30 \%$. Resep adonan kerupuk serta cara pengolahannya seperti yang digunakan untuk pembuatan kerupuk pada penggunaan flavor udang cair yaitu: tepung tapioka $1 \mathrm{~kg}$, telur ayam 4 butir, garam $10 \mathrm{~g}$, gula $10 \mathrm{~g}$, dan soda kue $8 \mathrm{~g}$ (Saleh et al., 1996). Kerupuk yang ditambah dengan tepung daging merah tuna yang disenangi panelis, dianalisis komposisi proksimatnya (kadar air, lemak, protein, dan abu) dibandingkan dengan kerupuk tanpa ditambah dengan tepung daging merah tuna.

\section{HASIL DAN BAHASAN}

\section{Proses Pemucatan}

Berdasarkan pengamatan secara visual ternyata pemucatan daging merah tuna dengan perendaman dalam larutan hidrogen peroksida lebih efektif daripada dalam larutan kaporit. Perendaman dalam larutan kaporit 2,5\% hingga 120 menit tidak tampak pengaruhnya karena daging masih tetap berwarna merah. Sebaliknya, perendaman daging merah tuna dalam larutan peroksida 1,0 persen selama 30 menit sudah cukup untuk memucatkan daging ikan sehingga berwarna putih kecoklatan

Pengamatan secara visual juga menunjukkan bahwa daging yang mengalami pemucatan dengan perendaman dalam larutan peroksida setelah pengukusan lebih cerah warnanya daripada yang direndam sebelum pengukusan. Pada prinsipnya, proses pemucatan (bleaching) adalah mengoksidas pigmen yang terikat sehingga warna pigmen menjadi lebih pucat (Young et al., 1962). Proses pemucatan warna merah pada pengolahan produk perikanan sering dilakukan untuk meningkatkan penampakan produk yang diinginkan. Hasil penelitian yang dilakukan Karmas (1982) menjelaskan bahwa daging ikan dapat dipucatkan pada $\mathrm{pH}$ netral, agak asam atau basa, yaitu sekitar pH 6,0 - 10,0 tanpa menurunkan mutu protein. Penggunaan senyawa hidrogen peroksida sebagai bleaching agent sering dilakukan pada kondisi agak alkalis. Residu hidrogen peroksida yang tertinggal dapat dihilangkan dengan cara antara lain, pencucian dengan air, penggunaan enzim katalase, penggunaan $\mathrm{Na}_{2} \mathrm{SO}_{3}$ dan kombinasi dari perlakuan tersebut (Karmas, 1982). Selama 
pemanasan tekstur daging menjadi lebih longgar, sehingga pada saat direndam dalam larutan peroksida permukaan daging yang terkena oksigen bebas menjadi lebih luas, dengan demikian lebih banyak pigmen yang teroksidasi dan ini mengakibatkan warna daging menjadi lebih pucat.

\section{Mutu Tepung Ikan}

\section{Komposisi proksimat}

Komposisi kimia tepung ikan yang dihasilkan adalah sebagai berikut: kadar air $7,86 \%$; protein $84,03 \%$; lemak $3,07 \%$; dan abu $1,88 \%$.

Berdasarkan standar yang disusun maka tepung ikan yang dihasilkan dapat digolongkan ke dalam konsentrat protein ikan tipe B (Buckle et al., 1987). Kriteria konsentrat protein ikan tipe B adalah kandungan protein minimum 65\%; air maksimum $10 \%$; lemak maksimum $3 \%$; klorida maksimum 1,5\%; $\mathrm{SiO}_{2}$ maksimum $0,5 \%$; lisin minirnum $6,5 \%$ dari protein, daya cerna pepsin minimum $92 \%$, bau dan rasa tidak ada spesifikasi. Sementara itu menurut Kulikov (1971), tepung ikan untuk pangan harus mengandung air tidak lebih dari $10 \%$, protein tidak kurang dari $70 \%$, lemak tidak lebih dari 0,5\%; garam tidak lebih dari $1,5 \%$ dan lisin tidak kurang dari $6,5 \%$. Secara deskriptif, tepung ikan yang dihasilkan mempunyai karakteristik sebagai berikut:

Rupa/warna : bersih, putih kekuningan

Bau : bau agak amis, spesifik tepung ikan

Konsistensi : cukup kering, seragam, dan tidak menggumpal

Berdasarkan hasil uji kualitatif dan kuantitatif diperoleh hasil bahwa tidak ditemukan residu $\mathrm{H}_{2} \mathrm{O}_{2}$ pada perlakuan pemucatan terhadap tepung ikan daging merah ikan tuna. Hal ini ditandai dengan tidak terlihatnya warna endapan kuning pada larutan sampel yang diberi larutan KI (Kalium lodida).

Hilangnya residu $\mathrm{H}_{2} \mathrm{O}_{2}$ ini dikarenakan telah larutnya (terurai) senyawa ini pada saat pencucian yang dilakukan setelah pemucatan. Pencucian dilakukan sebanyak tiga kali dengan menggunakan air. Dengan demikian tepung daging merah ikan tuna yang dipucatkan dengan $\mathrm{H}_{2} \mathrm{O}_{2}$ ini akan aman jika digunakan untuk campuran pada pengolahan pangan.

\section{Komposisi asam amino tepung daging merah tuna}

Untuk mengetahui kelayakan tepung daging merah tuna sebagai sumber gizi jika dimanfaatkan dalam pengolahan produk untuk tujuan pengkayaan pangan, dilakukan analisis komposisi asam amino yang hasilnya dapat terlihat dalam Tabel 1.

Tabel 1. Komposisi asam amino tepung daging merah tuna, konsentrat protein hering dan tepung kedelai Table 1. Amino acid composition of tuna red meat flour, herring hydrolysate and soybean meal

\begin{tabular}{lcccc}
\hline \multicolumn{1}{c}{$\begin{array}{c}\text { Asam amino (\%) } \\
\text { Amino acid (\%) }\end{array}$} & A & B* & C* \\
\hline Aspartat(Aspartat acid) & 4.89 & - & - \\
Treonin (Threonine) & 4.35 & 5.24 & 4.3 \\
Serin (Serin) & 3.61 & - & - \\
Glutamat (Glutamic acid) & 5.66 & - & - \\
Glisin (Glycine) & 2.23 & - & - \\
Alanin (Alanine) & 2.93 & - & 5.2 \\
Valin (Valine) & 3.43 & 5.16 & 1.4 \\
Metionin (Methionine) & 2.04 & 2.94 & 4.8 \\
Isoleusin (Isoleucine) & 4.31 & 4.47 & 7.6 \\
Leusin (Leucine) & 5.13 & 5.7 & 3.8 \\
Tirosin (Tyrocine) & 5.87 & 3.17 & 5 \\
Fenilalanin (Phenylalanine) & 5.2 & 4.46 & - \\
Amonia (Ammonia) & 1.68 & - & - \\
Lisin (Lysine) & 11.7 & 9.14 & - \\
Arginin (Arginine) & 9.2 & - & - \\
Histidin (Histidine) & 3.2 & - & \\
\hline
\end{tabular}

Keterangan/Notice:

$\mathrm{A}=$ tepung daging merah tuna (tuna red meat flour), $\mathrm{B}=$ konsentrat hidrolisat ikan hering (herring concentrate hydrolisate)

$C=$ tepung kedelai (soybean meah), $\left(^{*}\right)=$ Halliday \& Disney dalam llyas $(1980)$ 
Pada Tabel 1 terlihat bahwa tepung daging merah ikan tuna mengandung semua asam amino esensial yang dibutuhkan oleh tubuh manusia. Dibandingkan dengan tepung ikan hering dan tepung kedelai, tepung daging merah tuna mengandung kadar asam amino tirosin, penilalanin, dan lisin yang lebih tinggi, namun untuk asam amino esensial lainnya lebih rendah. Dengan demikian tepung daging merah tuna mempunyai prospek yang cukup baik untuk dimanfaatkan pada pengkayaan produk pangan yang mengalami defisiensi asam amino tersebut.

\section{Pemanfaatan tepung daging merah tuna}

Hasil percobaan pernanfaatan tepung daging merah ikan tuna sebagai suplemen dalam pembuatan kerupuk menunjukkan bahwa jumlah tepung daging merah ikan tuna yang ditambahkan ke dalam adonan kerupuk maksimum adalah 10\% (Tabel 2).
Kerupuk yang ditambah dengan tepung daging merah ikan tuna $10 \%$ mempunyai kadar protein dan lemak yang lebih tinggi daripada kerupuk yang tidak ditambahkan dengan tepung daging merah ikan tuna sebagai kontrol (Tabel 3).

\section{KESIMPULAN}

(1). Perlakuan perendaman daging merah ikan tuna dalam larutan hidrogen peroksida 1,0\% selama 30 menit cukup efektif untuk pemucatan warna daging. Proses pemucatan lebih efektif jika daging ikan dikukus terlebih dahulu sebelum perendaman.

(2). Tepung daging merah ikan tuna mengandung asam amino lisin sesuai dengan yang dipersyaratkan bagi tujuan bahan pangan

(3). Tepung daging merah ikan tuna dapat digunakan pada pengkayaan protein kerupuk hingga $10 \%$.

Tabel 2. Nilai organoleptik kerupuk yang diolah dari adonan yang mengandung tepung daging merah tuna Table 2. Organoleptic score of fish cracker containing tuna red meat flour

\begin{tabular}{ccccc}
\hline $\begin{array}{c}\text { Jumlah tepung tuna (\%) } \\
\text { Tuna meat flour (\%) }\end{array}$ & $\begin{array}{c}\text { Penampakan } \\
\text { Appearrance }\end{array}$ & $\begin{array}{c}\text { Bau } \\
\text { Odor }\end{array}$ & $\begin{array}{c}\text { Rasa } \\
\text { Taste }\end{array}$ & $\begin{array}{c}\text { Kerenyahan } \\
\text { Crispiness }\end{array}$ \\
\hline 0 & 8.2 & 6.7 & 7.1 & 8.2 \\
5 & 8.1 & 7.2 & 7.0 & 8.0 \\
10 & 7.7 & 7.4 & 7.4 & 7.8 \\
15 & 7.4 & 7.8 & 7.5 & 5.4 \\
20 & 6.2 & 7.8 & 7.8 & 4.5 \\
25 & 5.6 & 7.5 & 7.0 & 4.0 \\
30 & 5.0 & 7.8 & 7.0 & 3.2 \\
\hline
\end{tabular}

Tabel 3. Komposisi kimia kerupuk yang tanpa dan yang ditambahkan tepung daging merah tuna

Table 3. Proximate composition of raw cracker with and without tuna red meat flour

\begin{tabular}{lccccc}
\hline \multicolumn{1}{c}{$\begin{array}{c}\text { Kerupuk } \\
\text { Cracker }\end{array}$} & $\begin{array}{c}\text { Air } \\
\text { Moisture }\end{array}$ & $\begin{array}{c}\text { Karbohidrat } \\
\text { Carbohydrat }\end{array}$ & $\begin{array}{c}\text { Protein } \\
\text { Protein }\end{array}$ & $\begin{array}{c}\text { Lemak } \\
\text { Lipid }\end{array}$ & $\begin{array}{c}\text { Abu } \\
\text { Ash }\end{array}$ \\
\hline $\begin{array}{l}\text { Tanpa tepung daging merah tuna } \\
\text { Without tuna red meat flour }\end{array}$ & 8.9 & 80.78 & 2.11 & 1.56 & 2.3 \\
$\begin{array}{l}\text { Dengan daging merah 10\% } \\
\text { With tuna red meat flour 10\% }\end{array}$ & 8.98 & 78.15 & 5.96 & 2.45 & 2.11 \\
\hline
\end{tabular}

Penambahan tepung daging merah tuna lebih dari $10 \%$ menyebabkan kerupuk yang dihasilkan warnanya lebih kusam dan kurang renyah. Sebaliknya jika penambahan tepung kurang dari 10\% menyebabkan intensitas rasa spesifik kerupuk ikan menjadi kurang. Kerupuk yang dihasilkan dari adonan yang mengandung $10 \%$ tepung daging merah tuna mempunyai penampakan dan kerenyahan yang cukup baik dengan rasa spesifik seperti layaknya kerupuk ikan.

\section{DAFTAR PUSTAKA}

Anonim. 1974. Metode dan Prosedur Pengujian Kimiawi Hasil Perikanan. Lembaga Penelitian Teknologi Perikanan, Jakarta. $99 \mathrm{pp}$.

Anonim. 1979. Kodeks Makanan Indonesia tentang Bahan Makanan Tambahan. Departemen Kesehatan. Jakarta. $118 \mathrm{pp}$.

Buckle, K.A., R.A. Edwards, G.H. Fleet, dan M. Wooton. 1987. Ilmu Pangan. Terjemahan oleh Hari Purnomo dan Adiono. U.I. Press. Jakarta. 
Kulikov. P.I. 1971. Production of Meal, Oil, and ProteinVitamin Preparation in the Fishing Industry. Amrind Publ, Co. PVT. New York. 253 pp.

Karmas, E. 1982. Meat Poultry and Sea Food Technology. Noyes Data Corp. Park Ridge. New Jersey.

Nursyam,.H., Darius., E. Suprayitno, Murniyati, dan I. Muljanah. 1998. Pemanfaatan limbah pengalengan ikan tuna (daging merah) sebagai hidrolisat protein serta aplikasinya dalam olahan produk pangan. Laporan Hasil Kerja Sama Penelitian ARMP II. Badan Litbang Pertanin. 25 Maret 1998. 70 pp.
Saleh, M., Murdinah, N. Hak, dan Tazwir. 1995 Pengolahan pasta ikan dari daging merah ikan tuna. Laporan Teknis Instalasi Penelitian Perikanan Laut Slipi Tahun Anggaran 1995/1996. 60 pp.

Saleh, M., A. Ahyar., Murdinah, dan N. Hak. 1996 Ekstraksi kepala udang menjadi flavour udang cair. Jurnal Penelitian Perikanan Indonesia. Vol. II. No. 1. p. 55-59.

Young, K.W., S.L. Neuman, A.S. Mc Gill, and R. Hardy. 1962. The use of dilute solutions of hidrogen peroxide to whiten fish flesh. In: E. Heen dan R. Kreuzer Fish in Nutrition (Eds.). Fishing News, England. p. 242-254. 